\title{
Role Stressors, Task-Oriented Norm and Job Satisfaction: A Longitudinal Study
}

\section{Estresores de Rol, Norma de Orientación a la Tarea y Satisfacción Laboral: Un Estudio Longitudinal}

\author{
Begoña Urien Angulo y Amparo Osca \\ Universidad Nacional de Educación a Distancia (UNED)
}

\begin{abstract}
In line with the Job Demands-Resources Model (JD-R) this study analyzes the role of task-oriented norm (job resource) and role stressors (job demands) to predict job satisfaction over time. In order to test this effect, a sample was gathered in a manufacturing setting at two different times. Hierarchical regression analysis tests the principal and the interaction effects of role stressors (role conflict and role overload) and task-oriented norm to predict job satisfaction. Results confirm the negative effect of role conflict at Time 1 on job satisfaction at Time 2 showing the relevance of setting priorities to neutralize the negative effect of this stressor. Moreover, these results show the interaction between task overload (Time 1) and task-oriented norm (Time 1) on job satisfaction (Time 2) after working together for more than one year as a permanent group. Discussion is focused on the structural work context and within group implications of these findings in real working settings.

Keywords: role stressors, task-oriented norm, job satisfaction, longitudinal study.
\end{abstract}

Resumen. Partiendo del Modelo de Demandas-Recursos (JD-R) este estudio analiza el papel de la norma de orientación a la tarea (recurso) en los estresores del trabajo (demandas) para predecir la satisfacción laboral. Este efecto se prueba en una muestra de trabajadores de la industria de automoción, efectuando la toma de datos en dos tiempos. La regresión jerárquica prueba las relaciones directas entre las variables y el efecto de la interacción de los estresores (conflicto de rol y sobre-carga de trabajo) y la orientación a la tarea para predecir la satisfacción. Los resultados confirman la relación negativa entre el conflicto de rol en Tiempo 1 y la satisfacción en Tiempo 2. Además, estos resultados muestran la interacción entre la sobre-carga de trabajo (Tiempo 1) y la orientación a la tarea (Tiempo 1) en la satisfacción laboral (Tiempo 2) cuando la muestra lleva trabajando más de un año en grupos. En la discusión indicamos las implicaciones de estos resultados para el contexto laboral de los grupos y para las relaciones intra-grupos en entornos reales de trabajo.

Palabras Clave: estresores de rol, norma de orientación a la tarea, satisfacción laboral, estudio longitudinal.

The Job Demands-Resources (JD-R) Model (Bakker \& Demerouti, 2007; Demerouti, Bakker, Nachreiner, \& Schaufeli, 2001) explains how two sets of employees' working conditions (job demands and job resources) relate to their psychosocial health and wellbeing, which in turn, are associated with several employees and organizational outcomes (Llorens, Schaufeli, Bakker, \& Salanova, 2007). This model has been tested in various countries and types of jobs such as blue collar workers (Bakker, Demorouti, De Boer, \& Schaufeli, 2003). According to this model, there are two independent processes that could impact on work outcomes. The "erosion process" points out that the persistence of job demands produces an over consumption of energy and may undermine employees' wellbeing, resulting in negative outcomes (e.g. lower levels of performance, job dissatisfaction, job disen-

La correspondencia sobre este artículo se enviará a Amparo Osca, Facultad de Psicología, Universidad Nacional de Educación a Distancia, Tribulete 14, 28012 Madrid. E-mail: aosca@psi.uned.es gagement, etc.) to the organization. On the other hand, the "motivational process" posits that job resources increase employees' motivation and produce positive emotions that may lead to positive results to the organization.

Job resources are referred to physical, psychological, social and organizational aspects of the job (Demerouti et al., 2001) and these resources play a more salient role in work contexts where work demands are higher (Hobfoll, 2002). Work environments can offer a lot of resources, thus, can increase the willingness of dedicating workers efforts and abilities to the task (Meijman \& Mulder, 1998). Some examples of these organizational resources are: supportive colleges, performance feedback, (Schaufeli \& Bakker, 2004; Schaufeli \& Salanova, 2007), job control, rewards and recognition (Koyuncu, Burke, \& Fiksenbarm, 2006) and goal orientation (Salanova, Bakker, \& Llorens, 2006).

Due to the global competition in the automotive sector, the level of technological and organizational com- 
plexity of these industrial sites (job demands) has increased over the last two decades. Group-based organizations have changed the relations at work as well as the number and type of tasks required. In these work settings, blue-collar workers have not only to accomplish the traditional manufacturing simple cognitive tasks (e.g. load-unload machines, keep an eye on the automatic machinery, ask for help when machines stop, etc.) but they also have to deal with the quality control, maintenance, logistics, problem solving, continuous improvement and some management tasks (e.g. tasks reassignment depending on group needs, share resources with other shifts or other lines' groups, follow up materials and tools' costs, etc.), demanding more cognitive abilities. Moreover, in these companies every employee has to be highly performance-oriented if the company wants to outperform their competitors so as to survive.

Even though these new tasks have enriched the present job of the workers (motivational process), these tasks, have also produced an increment in workers job demands (role conflict and role overload) at the same time. However the relation between job demands and positive attitudes at work could be more complex than the JD-R model sugests. Cavanaugh, Boswell, Roehling, \& Boudreau (2000) considered that job demands are divided into two factors. Challenge-related stressors (e.g. work overload) might create an opportunity for personal development and hindrancerelated stressors (e.g. role conflict) might block employees' personal growth.

In line to the JD-R model and the manifold relations that job demands could establish with job attitudes, this paper seeks to test whether the new job demands arisen from implementing a group-based organization, might produce a positive effect by increasing workers motivational levels or not. Furthermore, this study tries to analyse the role of the job resource task-oriented norm to explain job attitudes (job satisfaction) over time.

\section{Job Demands in Groups: Role Conflict and Role Overload}

According to Demerouti et al. (2001), job demands refer to those physical, social or organizational aspects of the job that require sustained physical or mental effort and are therefore associated with certain physiological and psychological costs (e.g. exhaustion). The long-term effect of this continuous effort may be the draining of an individual's energy and a state of breakdown or exhaustion. In this line, the new job requirements associated with working in groups may have a negative effect on workers by increasing occupational risks (Askenazy, 2001; Bauer, 2004; Brenner, Fairris, $\&$ Ruser, 2004).

From the perspective of the European Foundation for the Improvement of Living and Working Conditions which edits the European working conditions surveys has reported in its latest release (ParentThirion et. al., 2012) a larger workload, more time pressure and more stress at work among team workers in several European countries (Finland, Spain, Great Britain, Denmark). These results suggest that the introduction of team-work could be associated with an intensification of workload and work demands (tighter deadlines and higher speed) and it has been happening in most European countries since 1992. This study also points out that the job satisfaction level with the working conditions has diminished.

Among the most common job demands associated with group-based organizations are role conflict and role overload. Role conflict refers to the incompatibility among role demands that could lead to employees' dissatisfaction and lower levels of performance (Rizzo, House, \& Lirtzman, 1970) while role overload is related to a situation in which work demands exceed the available resources that the people have to meet (Gilboa, Shirom, Fried, \& Cooper, 2008).

Several meta-analysis studies (Eatough, Chang, Miloslavic, \& Johnson, 2011; Fisher \& Gitelson, 1983; Gilboa et al., 2008; Griffeth, Hom, \& Gaertner, 2000; Jackson \& Shuler, 1985; LePine, Podsakoff, \& LePine, 2005; Mathieu \& Zajac, 1990), have shown the negative effect of role stressors (e.g. role conflict and role overload) on job performance and other job attitudes (e.g. job satisfaction and organizational commitment) among other outcomes in various working settings such as marketing, sales (Brown \& Peterson, 1993) or industrial sites (Fried, Ben-David, Tiegs, Avital, \& Yeverechahu, 1998). The mechanism behind these effects is consistent with the idea that these role stressors tend to evoke negative emotions and attitudes (Boswell, Olson-Buchanan, \& LePine, 2004).

Cavanaugh et al. (2000), state that the relation between role stressors (job demands) and job performance and job satisfaction can be more complex. These researchers conceptualized a two factors model to explain work stress. The first factor comprised high levels of workload, time pressure, job scope and responsibility and it was labelled "challenge-related stressors", because employees assessed that these job demands would create an opportunity for personal development. The second factor included role ambiguity, role conflict, job security and organizational politics and was named "hindrance-related stressors" as employees perceived them as obstacles to their personal growth. Challenge-related stressors were positively related to job satisfaction whereas hindrance-related stressors established a negative relation with that criteria variable. In a latter meta-analytical regression over 99 correlations, Podsakoff, LePine, \& Lepine, (2007) showed that both role stressors explained $37 \%$ of job satisfaction variance confirming the positive effect of challenge-related stressors and the negative effect of 
hindrance-related ones. Beehr, Glaser, Canali, \& Wallwey (2001) reported a positive relationship between employee job demands and job satisfaction in a sample of North-American workers. Another study reported that quantitative workload was positively related to job satisfaction (Dwyer \& Ganster, 1991).

Gilboa et al. (2008) considered that role stressors could be associated with more than one category (hindrance vs. challenge). According to these authors, we could expect a manifold relationship between role stressors and job outcomes because stressors might influence both categories depending on how people asses the job situation (Bettencourt \& Brown, 2003; Eatough et al., 2011).

With regard to role conflict people may negotiate with the different task's givers some priorities over their assignments resulting in a positive effect on job satisfaction. In relation to role overload it could be regarded as a hindrance stressor when job demands are larger than the available resources that people may have but on the other hand, high performers might take more tasks and responsibilities and might be motivated to perform them well.

In the literature review most articles address this topic more from a well-being perspective than a pure organizational one. Moreover, only a limited number of studies have examined the longitudinal effects of work stressors on psychological outcomes, and the results are inconsistent (Snow, Swan, Raghavan, Connell, \& Klein, 2003). Hackne, Peeters, \& Perhoniemi, (2011) reported a significant relation between job resources at Time 1 and family-work enrichment at Time 2. Other investigations have demonstrated long-term detrimental effects of work and work-family conflict stressor (Frone, Russell, \& Cooper, 1997) while others (Aneshensel \& Frerichs, 1982) found that the effects of work stressors are often restricted to a more limited time period and have little relationship to the effects experienced at later periods. In this respect, this article seeks to contribute to clarify the effect of role stressors on job satisfaction over time.

Hypothesis 1: role conflict at Time 1 is negatively related to job satisfaction at Time 1 and Time 2 (hypothesis 1a) and role overload at Time 1 is negatively related to job satisfaction at Time 1 and Time 2 (hypothesis $1 b$ ).

\section{Job Resources: Main and Buffering Effects of Task- oriented norm Over Time}

In line with the Job Demands-Resources Model, job resources refer to those physical, psychological, social, or organizational aspects of the job that may be functional in achieving work goals, reduce job demands at the associated physiological and psychological costs and/or stimulate personal growth and development (Demerouti et al., 2001). According to this definition, task-oriented norm can be considered as a functional organizational job resource in order to achieve work goals (Salanova et al., 2006), that might help to cope with the new job demands arisen from a group-base organization. Group norms have a great impact on how group members perceive and interact with one another. When workers acknowledge the norms as appropriate, these norms could increase group effectiveness (Mullen \& Copper, 1994) and job satisfaction.

Goal orientation is a complex construct conceptualized from several points of view (performance versus learning; trait versus situational; one-dimensional versus multidimensional) but there is a certain agreement on its positive effect in order to explain performance, motivation and affective states (Porter, 2005; SteeleJohnson, Beauregard, Hoover, \& Schmidt, 2000). Task-oriented norm might direct individual behaviour towards the common goal. Moreover, it might provide the motivational level to persist in exerting the effort required to accomplish group's goal (Weingart, 1992). According to González-Romá \& Peiró (1999), taskoriented norm is one of the processes that characterized one group or organization psychosocial climate.

Job resources, due to their (intrinsic and extrinsic) motivational potential, foster employees to meet their goals. In turn, employees may become more committed to their job, because they derive fulfillment from it (Hackman \& Oldham, 1980). In addition to these main effects, the JD-R model proposes that job resources influence the relationship between job demands and physical and psychological outcomes. Under demanding work conditions, employees who hold high levels of resources dispose of more supplies and, thus, are more capable of dealing with these demands (Bakker et al., 2003).

From the perspective of the group formation and development where time is an important variable, taskoriented norm can be considered more related to how group members interact and agree on some basic rules of behaviour (process). Moreover, most researchers agree on the fact that the more the time working together, the better the results the group achieves (Burke, Stagl, Salas, Pierce, \& Kendall, 2006; McGrath, 1964; Moreland \& Levine, 1982). However, this relation has not yet been clearly established.

In recent group effectiveness models (LePine, Piccolo, Jackson, Mathieu, \& Saul, 2008; Mathieu, Maynard, Rapp, \& Gilson, 2008), task or goal oriented norm could be regarded as a transition processes or as an emergent state. If we consider this norm as a "transition process" we would underlie activities such as mission analysis, goal specification, planning and formulated strategies what is congruent with group development approaches (Morgan \& Krueger, 1993). On the other hand, we can define this norm as the emergent 
state climate, defined as "the set of norms, attitudes and expectations that individuals perceive to operate in a specific social context" (Pirola-Merlo, Härtel, Mann, \& Hirst, 2002: 564) in relation to group tasks. We can reconcile both approaches due to the fact that the latter definition highlighted the attitudinal aspects needed to be developed within the group so as to trigger the adequate task-oriented behaviour (first definition) in group members.

In their meta-analysis, Lepine et al. (2008) found a significant positive relation among transition process and job satisfaction particularly between goal specification defined as activities centred on the identification and prioritization of team goals. Salanova et al., (2006), tested the goal orientation norm in a study on the impact of organizational and personal resources on job attitudes (work engagement), finding significant and positive relations between these two variables.

Hypothesis 2: Task-oriented norm at Time 1 is positively related to job satisfaction at Time 1 and Time 2.

In line with the JD-R model, task-oriented norm (job resource) would exert a motivational effect as workers understand better, share their group goals and agree on persists in working hard until the group goals were attained. In this context, role conflict and role overload (job demands), might lost some of its hindrance effect resulting in an increment of job satisfaction. In other words, when team members have high levels of task-oriented norm they might overcome the negative effects of role stressors on job satisfaction better than when this resource level is low.

In a similar way, Bradley, Postlethwaite, Klotz, Hamdami, \& Brown (2012) have reported that psychological safety climate (job resource) exerts an interaction effect between task conflict (job demand) and team performance (criteria variable) in the sense that when the psychological safety climate is positive, task conflict establishes a positive relation to team performance. This study also reveals that this interaction emerged using time lags between psychological safety, the stressor and the criteria variable, which suggests that, before the group could benefit from the positive conflict, an appropriate climate must be developed.

Apart from this study and despite the fact that this variable has been considered vital in explaining individual and group job satisfaction, its potential buffering effect has not yet been extensively studied.

Hypotheses 3: the stronger the task-oriented norm at Time 1 is, the less negative effect role conflict has on job satisfaction at both times (hypothesis $3 a$ ) and the stronger the task-oriented norm at Time 1 is, the less negative effect role overload has on job satisfaction at both times (hypothesis $3 b$ ).

\section{Method}

\section{Procedure}

This study was designed and conducted immediately after a major technological and organisational change was implemented in an automotive manufacturing company. Some members from our research team were involved in this process as external consultants cooperating with the company at the design and implementation stages. In order to gather the data, a longitudinal study was designed and carried out over two periods of time. The first data collection was gathered after each member had worked in this new organization for at least a six-month period of time. The second data collection was accomplished a year after the first one.

First data gathering was done at the end of the formal first follow-up session and second collection was carried out after the follow-up session a year later. These data measurements were taken in order to find out some improvement areas in each group. Questionnaire's results were presented to all groups and their managers as a part of this follow-up process so as to identify some areas of continuous improvement for both the teams and their managers. It means that all the subjects shared the same context and the reason why the process was being assessed.

\section{Sample}

The sample consisted of 130 workers of 15 groups (Group size: mean $=12$; s.d. $=1.66)$ at Time $1(\mathrm{~T} 1)$ and 107 of 10 groups (Group size: mean $=11$, s.d. $=2,90$ ) at Time 2 (T2). The sample size reduction at Time 2 was due to the fact that the level of sales forecasted by the company was not met so that the night shift was removed as well as some members from other teams. No significant difference between the original sample and the drop-outs was expected as the changes were decided by the company. However, in order to validate this point, several t-tests between the Time 1 and Time 2 samples were carried out among both the predictive and criteria variables. The obtained results confirmed our expectations (Job satisfaction: $\mathrm{F}=.89, \mathrm{p}=.58$; Role overload: $\mathrm{F}=.58, \mathrm{p}=.81$; Role conflict: $\mathrm{F}=1.1$, $\mathrm{p}=.34$; Task-oriented norm: $\mathrm{F}=.48, \mathrm{p}=.94$ ).

The sample at both times had to manufacture the most important components of a car engine working in autonomous groups. These groups consisted of multiskilled blue collar workers with previous working experience in the same company. Each group was responsible for several group outcomes such as: production, quality, maintenance, problem solving and continuous improvement tasks. Besides, these groups could reassign their tasks to their members depending on what the group needs were so as to achieve their 
planning outcomes. Another important characteristic was the high level of interdependence among groups belonging to the same production line.

With regard to the socio-demographical aspects, the workers were men only and most people were between 27 and 36 years old (48.52\%) followed by a second group between 18 and 26 years old (21.48\%), 16.29\% were in the 37 to 46 range and finally $1.49 \%$ of the sample was from 57 to 65 years old. In relation to the level of studies, the largest group $(60.9 \%)$ consisted of members with a medium vocational education qualification (FPII) followed by a $16.15 \%$ basic vocational level qualification. In third place were a $7.69 \%$ with secondary school and the rest had either a primary school education or no specific formal qualification.

\section{Measures}

Variables were measured using the same questionnaire at both times. Since the data gathering was carried out in a formal working session the response rate was $98.46 \%$. All scales ranged from 1 "not at all" to 5 "very much".

Role conflict. Was measured with Rizzo et al., (1970) scale, adapted and validated by Peiró, Meliá, Torres, \& Zurriaga (1986). This scale (6 items) asked to what extent the subjects had to deal with incompatible demands, lack of resources or unnecessary tasks ("I receive incompatible demands from two or more people").

Role Overload. This scale consists of three items and was designed for this research and it was made up of three items asking whether the workers could deal with their current workload, the current work pace demanded for the job and to what extent they had to make more effort than before to get the work done ("To what extent do you agree with the following statement? Currently we are working at a higher pace than before").

Task-oriented norm. This three item scale was based on a larger questionnaire on cultural norms (Kilman \& Saxon, 1983). "Task orientation" factor sub-scale had only been applied since it was the only relevant one to our research. It asked respondents whether the group's aims were the same for all team members, the extent to which the group members considered essential to persist in working hard until they meet the targets and to what extent this effort was shared among all team members ("Do you agree with the following statement?: In my team we consider essential to maintain the necessary effort so as to meet the results and objectives that have been set to our unit and shift").

Job satisfaction. This scale is formed by 8 items was designed based on the classic dimensions of job satisfaction. The scale asked for the satisfaction level with work group mates, supervisors, new working system, rewards and group outcomes ("Are you satisfied with the relationships that you maintain with other working units, shifts and teams?") .

Control variable: Time tenure. The time working in the same team was used as a control variable. The subjects of our study had worked in the same group for at least six months by the time we conducted the first data gathering.

\section{Results}

Table 1 provides the means, standard deviations, correlations and internal consistency (Cronbach's alpha) for all variables. Reliability coefficients were satisfactory.

In order to verify the hypotheses, several hierarchical regression analyses were carried out. Variables were introduced by blocks into the regression equation. Time tenure at Time 1 was used as a control variable. In Step 2 we entered the main effects of role conflict and role overload. In Step 3 we added the main effect of task-oriented norm and finally in Step 4 we entered the product term for the interaction between role stressors and task-oriented norm. Earlier, new variables were created by multiplying the value of the variables included in the interaction terms (role stressors by task-oriented norm). We examined the change in variance explained $\left(\Delta R^{2}\right)$ in Step 4 to assess the interaction.

Regarding Hypotheses 1a at Time 1, the hierarchical regression analysis depicts in Table 2 shows that role conflict establishes a direct significantly negative relation with job satisfaction at Time $1(\mathrm{~B}=-.33, p<.001)$.

Table 1. Means, standard deviations, correlations and scale reliabilities

\begin{tabular}{|c|c|c|c|c|c|c|c|c|}
\hline Variable & $M$ & $S D$ & 1 & 2 & 3 & 4 & 5 & 6 \\
\hline 1. Time Tenure T1 & 12.81 & 5.31 & & & & & & \\
\hline 2. Role Conflict T1 & 2.42 & .65 & .12 & $(.76)$ & & & & \\
\hline 3. Role Overload T1 & 2.90 & .65 & .04 & -.05 & $(.70)$ & & & \\
\hline 4. Task-Oriented Norm T1 & 3.99 & .52 & -.00 & $-.48 * *$ & -.14 & $(.74)$ & & \\
\hline 5. Job Satisfaction T1 & 4.01 & .48 & .04 & $-.46 * *$ & -.12 & $.62 * *$ & $(.77)$ & \\
\hline 8. Job Satisfaction T2 & 4.09 & .47 & -.03 & $-.41 * *$ & -.08 & $.44 * *$ & $.40 * *$ & $(.79)$ \\
\hline
\end{tabular}

Note. Cronbach's alpha appears along the diagonal in parenthesis. N T1 $=130$ workers. N T2 $=107$ workers

$* * \mathrm{p}<.01$ 
Table 2. Moderated regression results of Role Conflict x Task-Oriented group norm on satisfaction Time 1

\begin{tabular}{lccc}
\hline Variable & Step 1 & Step 2 & Step 3 \\
\hline Control Variable & & & Step 4 \\
$\quad$ Time Tenure T1 & .00 & .00 & .00 \\
Main Effects & & $-.33^{* * *}$ & $-.17^{* * *}$ \\
$\quad$ Role Conflict T1 & & & $.44^{* * *}$ \\
$\quad$ Task Oriented Nom T1 & & & $-.68^{*}$ \\
Interaction Effect & .003 & .200 & .12 \\
$\quad$ Role Conflict x Task Oriented & 0.30 & $14.25^{* * *}$ & .379 \\
$\mathrm{R}^{2}$ Model F change & .003 & $.197^{* * *}$ & $23.60^{* * *}$ \\
$\Delta \mathrm{R}^{2}$ & & $.179^{* * *}$ & .391 \\
\hline
\end{tabular}

Note: Coefficients reported are non-standardized regression coefficients. $N \mathrm{~T} 1=130$ workers.

$* * * p<.001 ; * * p<.01 ; * * * p<.05$

Role conflict maintains its negative predictive effect across the 4 models tested. From these results we can corroborate our hypothesis 1a with regard to the role conflict.

In Time 2 same effects are found $(\mathrm{B}=-.27, p<$ $.001)$. Role conflict maintains its direct negative predictive effect even though group members have been working together more than a year.
In relation to Hypothesis $1 \mathrm{~b}$, role overload establishes a direct positive connection with job satisfaction at Time 1 in Step $3(\mathrm{~B}=.18, p<.001)$, but this effect is lost when the interaction effect is added to the equation in Step 4. However, the direction of the relation changes in Time 2 becoming negative at Step $4(\mathrm{~B}=$ $-1.6, p<.01)$. These results only confirm the Hypotheses $1 \mathrm{~b}$ at Time 2 .

Table 3. Moderated regression results of Role Conflict x Task-Oriented group norm on satisfaction Time 2

\begin{tabular}{|c|c|c|c|c|}
\hline Variable & Step 1 & Step 2 & Step 3 & Step 4 \\
\hline \multicolumn{5}{|l|}{ Control Variable } \\
\hline Time Tenure T1 & -.00 & -.00 & -.00 & -.00 \\
\hline \multicolumn{5}{|l|}{ Main Effects } \\
\hline Role Conflict T1 & & $-.27 * * *$ & $-.16^{* *}$ & $-.88^{*}$ \\
\hline Task Oriented Nom T1 & & & $.30 * * *$ & -.11 \\
\hline \multicolumn{5}{|l|}{ Interaction Effect } \\
\hline Role Conflict x Task Oriented & & & & .18 \\
\hline $\mathrm{R}^{2}$ & .001 & .137 & .221 & .245 \\
\hline Model F change & 0.05 & $6.58 * *$ & $7.73 * * *$ & $6.57 * * *$ \\
\hline$\Delta \mathrm{R}^{2}$ & .001 & $.138 * * *$ & $.083^{* *}$ & .024 \\
\hline
\end{tabular}

Note: Coefficients reported are non-standardized regression coefficients. $N \mathrm{~T} 1=130$ workers.

$* * * p<.001 ; * * p<.01 ; * * * p<.05$

Table 4. Moderated regression results of Role Overload x Task-Oriented group norm on satisfaction Time 1

\begin{tabular}{|c|c|c|c|c|}
\hline Variable & Step 1 & Step 2 & Step 3 & Step 4 \\
\hline \multicolumn{5}{|l|}{ Control Variable } \\
\hline Time Tenure T1 & .04 & .04 & .01 & .01 \\
\hline \multicolumn{5}{|l|}{ Main Effects } \\
\hline Role Overload T1 & & .10 & $.18 * * *$ & -.02 \\
\hline Task Oriented Nom T1 & & & $.58 * * *$ & .43 \\
\hline \multicolumn{5}{|l|}{ Interaction Effect } \\
\hline Task Intensity x Task Oriented & & & & .05 \\
\hline $\mathrm{R}^{2}$ & .002 & .022 & .400 & .401 \\
\hline Model F change & 0.24 & 1.31 & $25.98 * * *$ & $19.41 * * *$ \\
\hline$\Delta \mathrm{R}^{2}$ & .002 & .022 & $.400 * * *$ & .401 \\
\hline
\end{tabular}

Note: Coefficients reported are non-standardized regression coefficients. $N \mathrm{~T} 1=130$ workers.

$* * * p<.001$ 
Table 5. Moderated regression results of Role Overload x Task-Oriented group norm on satisfaction Time 2

\begin{tabular}{|c|c|c|c|c|}
\hline Variable & Step 1 & Step 2 & Step 3 & Step 4 \\
\hline \multicolumn{5}{|l|}{ Control Variable } \\
\hline Time Tenure T1 & -.00 & -.00 & -.00 & -.00 \\
\hline \multicolumn{5}{|l|}{ Main Effects } \\
\hline Role Overload T1 & & -.06 & -.02 & $-1.6^{* *}$ \\
\hline Task Oriented Nom T1 & & & $.40 * * *$ & $-.79 \dagger$ \\
\hline \multicolumn{5}{|l|}{ Interaction Effect } \\
\hline Task Intensity x Task Oriented & & & & $.39 * *$ \\
\hline $\mathrm{R}^{2}$ & .001 & .009 & .191 & .256 \\
\hline Model F change & 0.10 & 0.37 & $6.51 * * *$ & $7.03 * * *$ \\
\hline$\Delta \mathrm{R}^{2}$ & .001 & .007 & $.182 * * *$ & .0 .65 \\
\hline
\end{tabular}

Note: Coefficients reported are non-standardized regression coefficients. $N \mathrm{~T} 1=130$ workers.

*** $p<.001 ; * * p<.01 ; * * * p<.05 ; \uparrow p=.07$

Figure 1. Interaction between role overload and task-oriented norm on job satisfaction at Time 2

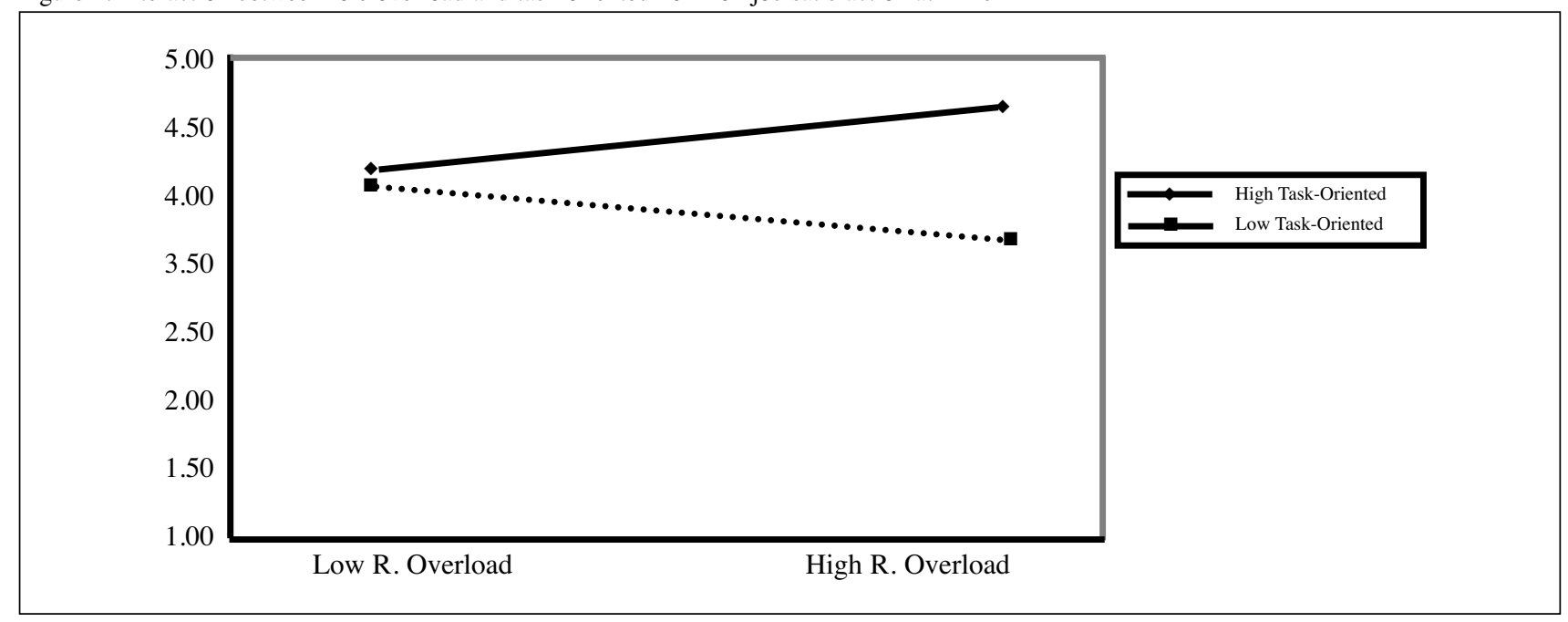

In relation to the Hypothesis 2, all equations at Step 3 confirm the significantly positive connection between task-oriented norm and job satisfaction at both times (role conflict T1: $\mathrm{B}=.44, p<.001 ; \mathrm{T} 2$ : $\mathrm{B}=$ $.30, p<.01$ and role overload T1 $\mathrm{B}=.58, p<.001 ; \mathrm{T} 2$ : $\mathrm{B}=.40, p<.001)$. However this predictive power is lost in Step 4. As the correlation between these two variables is also significant we can accept the Hypothesis 2 due to these results.

With regard to the Hypotheses $3 \mathrm{a}$ and $3 \mathrm{~b}$, we have to analyse the interaction effects. Neither at Time 1 nor at Time 2 is the interaction effect of role conflict and task-oriented norm relevant to explain job satisfaction $(\mathrm{T} 1: \mathrm{B}=.13, p>.05 ; \mathrm{T} 2: \mathrm{B}=.18, p>.05)$. Step 3 , in both times, is the one that best explains the criteria variable $(\mathrm{T} 1: \mathrm{F}=23.60, p<.001 ; \mathrm{T} 2: \mathrm{F}=7.73, p<$ $.001)$. In this model task-oriented norm is the variable that best predicts job satisfaction at both times (T1: B $=.30, p<.001 ; \mathrm{T} 2: \mathrm{B}=.44, p<.001)$. Role conflict is the variable that establishes a significant negative relationship with job satisfaction in both times in Model 4. Model 4 accounts for the $39.1 \%$ of job satisfaction in
Time 1 and $24.5 \%$ in Time 2 . From these results, Hypothesis $3 \mathrm{a}$ has to be rejected.

With regard to the Hypothesis $3 b$, the hierarchical analysis performed at Time 1 (Table 4) shows that the third model is the one that best fits to explain job satisfaction $(\mathrm{F}=25.98, p<.001)$. In this model role overload establishes a significant positive effect on job satisfaction $(\mathrm{B}=.18, p<.001)$. However interaction effect between this variable and task-oriented norm has not turned out to be statistically significant (T1: B = $.05, p>.05)$.

As shown in Table 5 there is a significant interaction between role overload and task-oriented norm $\left(\Delta R^{2}=\right.$ $.06, p<.01)$ so that the latter variable moderates the effect of role overload on job satisfaction (T2: $\mathrm{B}=.39$, $p<.01)$. Job satisfaction is best explained by Step 4 in this case $(\mathrm{F}=7.03, p<.001)$. The explained variance of the interaction has increased a $6.5 \%$ comparing to Step 3.

Figure 1 illustrates how job satisfaction increases when high role overload levels are combined with a high task-oriented norm whereas job satisfaction 
decreases when high role overload levels are combined with a low task-oriented norm. These results partially confirm our Hypothesis $3 \mathrm{~b}$ with regard to Time 2.

\section{Discussion}

This paper analyzed the direct and modulated role of two role stressors (demands) and task-oriented norm (resource) to explain job satisfaction over a period of time. The study was conducted within a real working context with the same sample in two different times a one-year gap between the first data gathering and the second one. At this point the lack of longitudinal studies on this subject should be underlined. Five main relevant findings were found in accordance to our results. Firstly (Hypothesis 1a), our data supports the negative direct effect of role conflict on job satisfaction in the sense that: the more role conflict, the less satisfaction with the job and this negative effect is maintained over time, as has also been reported extensively in earlier research (Eatough et al., 2011; Fisher \& Gitelson, 1983; Gilboa et al., 2008; Griffeth et al., 2000; Jackson \& Shuler, 1985; LePine et al., 2005; Mathieu \& Zajac 1990). In line with the two-factor stressors theory (Cavanaugh et al., 2000; Podsakoff et al., 2007), our results confirm the hindrance effect of role conflict in our sample.

Secondly, despite the objective increment of employees' workload, this predictor did not establish a direct relationship with job satisfaction (Hypothesis $1 b)$. But it establishes significant relations when it was introduced in two hierarchical regression models. The direction of the relation is different depending on the time the sample has been working as a group. When group members have worked together for less than a year, the relation is positive whereas the groups that have worked together for more than a year the relation turns negative. From the JD-R model we could have expected a significant negative relation between the two variables at both Times. From the challenge-hindrance model and according to Beehr et al. (2001), the workers from our samples are engaged in a highly demanding sector and they are used to competing not only against other car manufacturers but also against other plants from the very same company. In this context demanding work might be perceived as challenging and employees would cope well with it. However, this stressor could have lost its challenging nature when workload represented a greater demand that exceeds workers resources. This change could have happened as the number of workers assigned to each group has been reduced from Time 1 (mean 12 members) to Time 2 (mean 11 members). These objective variation, could have turned the assessment of the situation from challenging to hindrance, due to the fact that more effort is demanded by the working situation, and as a result the direction of the relation to job satisfaction become negative (Gilboa et al., 2008).
The third main finding (Hypothesis 2) is that taskoriented norm confirms an important role in explaining job satisfaction (Lepine et al., 2008). The sense of sharing this resource among group members might exert a motivational effect as workers share the same believe (to work hard until we meet them) regarding the group goals. This believe could induce positive emotions and, consequently, producing an incremental effect on job satisfaction (Schaufeli, Bakker, \& van Rhenen, 2009).

Fourthly, since no interaction effect has been found between role conflict and task-oriented norm on job satisfaction (Hypothesis 3a), this result might suggest that role conflict negative effect has not lessened even when group members have developed a strong taskoriented norm or have worked in the same group for more than one year. Our last significant finding is that task-oriented norm interacts with role overload which means that job satisfaction increases (Hypothesis 3b). This effect has been found when employees have been working for over a year in the same group. As we mentioned earlier in this part of the article, an objective change in the amount of people assigned to each group has happened from Time 1 to Time 2 . In this more pressing work situation, this result suggests that a strong group norm could be important to avoid the possibly negative effect that excessive demanding jobs might have on job satisfaction, in line with the JD-R model. As has been earlier mentioned, from the hindrance and challenge role stressors dimensions (Gilboa et al., 2008), role overload has both strong hindrance and challenge components. Despite the fact that the main variables that might buffer the perception of role overload have not yet been clearly established, our finding highlights the relevance of task-oriented norm as modulating role overload and job satisfaction when work conditions become tighter, at least in a type of organizations where goal-orientation is a must.

Considering our findings and from an applied perspective we would like to highlight the following points:

- As job demands are a structural variable, managers should make a real effort in prioritizing the responsibilities to group members when necessary (e.g., tighter deadlines). This would seem to be a useful tactic to avoid the negative effects of inconsistency on the various demands made on employees' level of satisfaction.

- Since complexity and flexibility increase, workers have to carry out more tasks involving cognitive skills. Managers should be aware of this fact and provide the necessary resources (e.g., task-goal orientation) to maintain the effect of challenge or to reduce the possible negative effect of workload on job satisfaction.

- It is essential that companies explicitly design jobs and implement management strategies so as to reinforce task orientation. This recommenda- 
tion might be considered a redundancy in real working contexts but we think that goal-setting practices should be also deployed at the shopfloor level aligning the rewards and recognition system with them.

- As a strong task-oriented norm significantly predicts job satisfaction managers should facilitate the development of positive attitudes towards common group goals, should maintain the persistence on these goals and the positive perception of group peers making the same effort. In addition, some time is needed so that these group' processes could exert their positive influence on job satisfaction.

Inevitably the nature of the study meant the imposition of some limitative constrains as to be conducted in a real working setting. These constrains must be surpass in future studies. In this respect, an important point that needs further analysis is the role that taskoriented norm plays as a buffering variable moderating the negative effect of job stressors on job satisfaction over time. Likewise it would be interesting to test these variables at group level (Bradley et al., 2012). Another area where more research should be carried out is the effect of role overload over time since it is not yet clearly established whether its effect might be relevant to explain job satisfaction and the direction of this effect. Besides, it could be worth working out whether this variable could be considered a job stressor (Cavanaugh et al., 2000; Podsakoff et al., 2007), a tasks characteristic (working conditions surveys) or both. With regard to role conflict further analysis would be necessary in order to test whether the relation between the dimensions of job satisfaction and this job demand change over time.

This study has confirmed the role of job demands and job resources on job satisfaction and the buffering effect of goal orientation as an organizational resource as well as a group process, on satisfaction in a sample autonomous work groups. Moreover, it has also contributed to making some progress from a longitudinal perspective and in real work settings. Additional research should be carried out in order to confirm these effects at the group level of analysis in the future.

\section{References}

Aneshensel, C. S., \& Frerichs, R. (1982). Stress, support, and depression: A longitudinal causal model. Journal of Com-munity Psychology, 10, 363-376.

Askenazy, P. (2001). Innovative workplace practices and occupational injuries and illnesses in the United States. Economic and Industrial Democracy, 22, 485-516.

Bakker, A. B., \& Demerouti, E. (2007).Towards a model of work engagement. Career Development International, 13, 209-223.

Bakker, A. B., Demorouti, E., De Boer, E., \& Schaufeli,W.
B. (2003). Job demands and job resources as predictors of absence duration and frequency. Journal of Vocational Behaviour, 62, 341-356.

Bauer, T. K. (2004). High performance workplace practices and job satisfaction: Evidence from Europe. IZA Discussion Paper Series, 1265, 1-33.

Beehr, T. A., Glaser, K. M., Canali, K. G., \& Wallwey, D. A (2001). Back to basics: Re-examination of DemandControl Theory of occupational stress. Work \& Stress, 15(2), 115-130.

Bradley, B. H., Postlethwaite, B. E., Klotz, A. C., Hamdami, M. R., \& Brown, G. B. (2012). Reaping the benefits of task conflict in Teams: The critical role of team psychological safety climate. Journal of Applied Psychology, 97, 151-158.

Bettencourt, L., \& Brown, S. (2003) Role stressors and customer-oriented boundary-spanning behaviours in service organizations. Journal of the Academy of Marketing Science, 31, 394-408.

Boswell, W. R., Olson-Buchanan, J. B., \& LePine, M. A. (2004). Relations between stress and work outcomes: The role of felt challenge, job control, and psychological strain. Journal of Vocational Behaviour, 64, 165-181

Brenner, M., Fairris, D., \& Ruser, J. (2004). Flexible Work Practices and Occupational Safety and Health: Exploring the Realtionship Between Cumulative Trauma Disorders and Workplace Transformation. Industrial Relations: A Journal of Economy and Society, 43, 242-266.

Brown, S. P., \& Peterson, R. A. (1993) Antecedents and consequences of salesperson job satisfaction: Meta-analysis and assessment of causal effects. Journal of Marketing Research, 30, 63-77.

Burke, C. S., Stagl, K. C., Salas, E., Pierce, L., \& Kendall, D. (2006). Understanding team adaptation: A conceptual analysis and model. Journal of Applied Psychology, 91, 1189-1207.

Cavanaugh, M. A., Boswell, W. R., Roehling, M. V., \& Boudreau, J. W. (2000). An empirical examination of selfreported work stress among U.S. managers. Journal of Applied Psychology, 85, 65-74.

Demerouti, E., Bakker, A. B., Nachreiner, F., \& Schaufeli, W. B. (2001). The job demands-resources model of burnout. Journal of Applied Psychology, 86, 499-512.

Dwyer D. J., \& Gangster D.C. (1991). The effects of job demands and control on employee attendance and satisfaction. Journal of Organisational Behaviour, 12, 595-608.

Eatough, E. M, Chang, Ch., Miloslavic, S. A., \& Johnson, R. E. (2011). Relationships of role stressors with organizational citizenship behavior: A meta-analysis. Journal of Applied Psychology, 96, 619-632.

Fisher, C. D., \& Gitelson, R. (1983). A meta-analysis of the correlates of role conflict and ambiguity. Journal of Applied Psychology, 68, 320-333.

Fried, Y., Ben-David, H. A., Tiegs, R. B., Avital, N., \& Yeverechyahu, U. (1998). The interactive effect of role conflict and role ambiguity on job performance. Journal of Occupational and Organizational Psychology, 71, 1927. 
Frone, M. R., Russell, M., \& Cooper, M.L. (1997). Relation of work-family conflict to health outcomes: A four-year longitudinal study of employed parents. Journal of Occupational and Organizational Psychology, 70, 325-335.

Gilboa, S., Shirom, A., Fried, Y., \& Cooper, C. (2008). A meta-analysis of work demand stressors and job performance: Examining main and moderating effects. Personnel Psychology, 61, 227-271.

González-Romá, V., \& Peiró, J. M. (1999). El clima en las organizaciones laborales y en los equipos de trabajo. Revista de Psicología General y Aplicada, 52, 269-285.

Griffeth, R. W., Hom, P. W., \& Gaertner, S. (2000). A metaanalysis of antecedents and correlates of employee turnover: Update, moderator tests, and research implications for the next millennium. Journal of Management, $26,463-488$.

Hackman, J. R., \& Oldham, G.R. (1980). Work Redesign. San Francisco: Addison-Wesley.

Hakanen, J. J., Peeters, M. C. W., \& Perhoniemi, R. (2011) Enrichment processes and gain spirals at work and at home: A 3-year cross-lagged panel study. Journal of Occupational and Organizational Psychology, 84, 8-30.

Hobfoll, S. E. (2002). Social and psychological resources and adaptation. Review of General Psychology, 6, 307324.

Jackson, S. E., \& Shuler, R. S. (1985). A meta-analysis and conceptual critique of research on role ambiguity and role conflict in work settings. Organisational Behaviour and Human Decision Processes, 36, 16-78.

Koyuncu, M., Burke, R. J., \& Fiksenbaum, L. (2006). Work engagement among woman managers and professionals in a Turkish bank: Potential antecedents and consequences. Equal Opportunities International, 25, 299-310.

LePine, J., Piccolo, R.F., Jackson, C. L., Mathieu, J. E., \& Saul, J. R. (2008). A meta-analysis of teamwork processes: Test of a multidimensional model and relationships with team effectiveness criteria. Personnel Psychology, 61, 273-307.

Lepine, J. A., Podsakoff, N. P., \& Lepine, M. A. (2005). Meta-analytic test of the challenge stressor-hindrance stressor framework: An explanation for inconsistent relationships among stressors and performance. Academy of Management Journal, 48, 764-775.

Llorens, S., Schaufeli, W. B., Bakker, A. B., \& Salanova, M. (2007). Does a positive gain spiral of resources, efficacy beliefs and engagement exist? Computers in Human Behavior, 23, 825-841.

Mathieu, J., Maynard, M. T., Rapp, T., \& Gilson, L. (2008). Team effectiveness 1997-2007: A review of recent advancements and a glimpse into the future. Journal of Management, 34, 410-476.

Mathieu, J. E., \& Zajac, D. M. (1990). A review and metaanalysis of the antecedents, correlates, and consequences of organizational commitment. Psychological Bulletin, 108, 171-194.

McGrath, J. E. (1964). Social psychology: A brief introduction. New York: Holt, Rinehart, and Wiston.

Meijman, T. F., \& Mulder, G. (1998). Psychological aspects of workload. In P. J. Drenth \& H. Thierry (Eds.), Handbook of work and organizational psychology, Vol, 2: Work psychology (pp. 5-33). Hove: Psychology Press.

Moreland, R. L. \& Levine, J. M. (1982). Socialization in Small Groups: Temporal Changes in Individual-Group Relations. In L. Berkowitz (Ed.), Advances in Experimental Social Psychology (pp 137-192). New York: Academy Press.

Morgan, D. L., \& Krueger, R. A.(1993). When to use focus groups and why. In D. L. Morgan (Ed.), Successful focus groups: Advancing the state of the art (pp. 3-19) Thousand Oaks, CA: Sage Publications, Inc.

Mullen, B., \& Copper, C. (1994). The relation between group cohesiveness and performance: An integration. Psychological Bulletin, 115, 210-227.

Parent-Thirion, A., Vermeylen, G., van Houten, G., LylyYrjänäinen, M., Biletta, I., Cabrita, J., \& Niedhammer, I. (2012). Fifth European Working Conditions Survey. Luxembourg: Eurofound, Publications Office of the European Union.

Peiró, J. M., Meliá, J. L., Torres, M. A., \& Zurriaga, R. (1986). La medida de la experiencia de la ambigüedad en el desempeño de roles: el cuestionario general de ambigüedad de rol en ambientes organizacionales. Evaluación Psicológica, 3, 27-53.

Pirola-Merlo, A., Härtel, Ch., Mann, L., \& Hirst, G. (2002). How leaders influence the impact of affective events on team climate and performance in $\mathrm{R} \& \mathrm{D}$ teams. The Leadership Quaterly, 13, 561-581.

Podsakoff, N. P., LePine, J. A., \& LePine, M. A. (2007). Differential challenge stressor-hindrance stressor relationships with job attitudes, turnover intentions, turnover, and withdrawal behavior: A meta-analysis. Journal of Applied Psychology, 92, 438-454.

Porter, C. O. L. H. (2005). Goal Orientation: Effects on backing up behavior, performance, efficacy and commitment in teams. Journal of Applied Psychology, 90, 811818.

Rizzo, J. R., House, R. J., \& Lirtzman, S. I. (1970). Role Conflict and Ambiguity in Complex Organizations. Administrative Science Quarterly, 15, 150-163.

Salanova, M., Bakker, A. B., \& Llorens, S. (2006). Flow at work: evidence for an upward spiral of personal and organizational resources. Journal of Happiness Studies, 7, 122.

Schaufeli, W. B., \& Bakker, A. B. (2004). Job demands, job resources and their relationship with burnout and engagement: A multi-sample study. Journal of Organizational Behavior, 25, 293-315.

Schaufeli, W. B., Bakker, A. B., \& van Rhenen, W. (2009). How changes in job demands and resources predict burnout, work engagement and sickness absenteeism. Journal of Organizational Behavior, 30, 893-917.

Schaufeli, W. B., \& Salanova, M. (2007). Work engagement: An emerging psychological concept and its implications for organizations. In S. W. Gilliland, D. D. Steiner \& D. P. Skarlicki (Eds.), Research in social issues in mamagement: Vol.5. Managing social and eth- 
ical issues in organizations. Greenwich, CT: Information Age Publishers.

Snow, D. L., Swan, S. C., Raghavan, Ch., Connells, Ch. M., \& Klein, I. (2003). The relationship of work stressors, coping and social support to psychological symptoms among female secretarial employees. Work \& Stress, 17, 241-263.
Steele-Johnson, D., Beauregard, R. S., Hoover, P. B., \& Schmidt, A. M. (2000). Goal orientation and task demand effects on motivation, affect, and performance. Journal of Applied Psychology, 85, 724-738.

Weingart, L. R. (1992). Impact of group goals, task component complexity, effort, and planning on group performance. Journal of Applied Psychology, 77, 682-693.

Manuscript Received: 19/07/2012

Revision Received: 22/10/2012

Accepted: 25/10/2012 